\title{
SUBJECTIVE WELL-BEING OF WOMEN IN THEIR LATE ADULTHOOD
}

\section{Lia Kaulina Suci Ningtyas, Fatwa Tentama*, Nina Zulida Situmorang *Correspondent Author}

\author{
Lia Kaulina Suci Ningtyas \\ Universitas Ahmad Dahlan \\ Jalan Kapas Nomor 9, Semaki, \\ Umbulharjo, Kota Yogyakarta, Daerah \\ Istimewa Yogyakarta \\ Indonesia \\ Email: lia.kaulina@gmail.com \\ Fatwa Tentama \\ Universitas Ahmad Dahlan \\ Jalan Kapas Nomor 9, Semaki, \\ Umbulharjo, Kota Yogyakarta, Daerah \\ Istimewa Yogyakarta \\ Indonesia \\ Email: fatwa.tentama@psy.uad.ac.id
}

Nina Zulida Situmorang

Universitas Ahmad Dahlan

Jalan Kapas Nomor 9, Semaki,

Umbulharjo, Kota Yogyakarta, Daerah

Istimewa Yogyakarta

Indonesia

Email: nina.situmorang@psy.uad.ac.id

Halaman

19-25

\begin{abstract}
This study aimed to describe senior women's subjective well-being and its underlying factor. This study was conducted in Yogyakarta and Madura with six senior women aged 60 years and above. Phenomenological qualitative study was applied. The data were collected using interview and observation. Data were analysed using content analysis. The participants were recruited using purposive sampling technique. This study found that the subjective well-being of late adults can be viewed from both cognitive and affective components: life satisfaction, health, productive activities, life enjoyment, and confidence. Some adverse effects were also revealed, such as feelings of loneliness, sadness, and stress. The result of other studies found that religiosity, social relations, leisure time, success and family support are contributing factors that influence the subjective wellbeing of late adult people. The results of the study can be used as a reference for counselors to consider senior women subjective well-being in providing guidance and counseling services. Efforts can be made to develop subjective well-being in senior women through elderly counseling.

Keywords: affective, life satisfaction, senior women, subjective well-being
\end{abstract}

\section{INTRODUCTION}

People strive to do their best at acquiring knowledge, working to earn more income, achieving success, going on vacation, and worshiping to meet the needs of the soul and body, ultimately leading to the acquisition of happiness. Happiness and life satisfaction are the main goals for most people (Suikkanen, 2011; Hofmann, et al., 2014; Ngamaba, 2016). Everyone craves happiness in their life because it signifies hope.

The term happiness is widely known in positive psychology. It is defined as the way someone judges their current and past experiences (Shipp, et al., 2009; Forgeard, et al., 2011; Rask, et al., 2009). According to Diener (1984), subjective well-being is a person's evaluation of his or her own life. This evaluation comes in the form of cognitive evaluation, consisting of life satisfaction and emotional evaluation in the form of how frequent someone experiences a positive (pleasant feelings) and negative affect (unpleasant feelings).

Everyone feels subjective well-being because everyone wants to live happily, including people in their late adulthood. 


\section{0| PSIKOPEDAGOGIA}

JURNAL BIMBINGAN DAN KONSELING

Vol.8, No.1, June 2019

According to Papalia, et al. (2009) aging are considered as one of the declining phases in the human life span. Late adulthood is the closing period of a series of processes of human development. This period starts from the age of sixty to death, characterized by physical and psychological decline. Psychologically, people in their late adulthood can suffer from mental health problems such as major depression, anxiety, loneliness, and emptiness syndrome. Physically, they may suffer from osteoporosis, decrease in various functions of the sensory organs, diseases of the urinary system, diabetes, poor heart conditions, high blood pressure, and arthritis (Santrock, 2012).

Data from The Ministry of Health of the Republic of Indonesia 2017 report that there are currently around 23.66 million older adults $(9.03 \%)$ in Indonesian population. The data also predicted that the elderly population would increase up to 33.69 million people by 2025 , roughly 40.95 million in 2030 , and 48.19 million people by the end of 2035 (Badan Pusat Statistik, 2017).

Data from the Yogyakarta Social Service states that the number of elderly people in Yogyakarta reaches 13 to 15 percent of the population. The number reaches 2,000 people in 2015 and increased up to 3,000 by 2017. Based on the 2017 happiness index Badan Pusat Statistik survey, the population tended to decline with increasing age. The population with the age of 24 years and lower has the highest Happiness Index of 71.29 percent. A similar condition applies to the dimensions of life satisfaction and meaningfulness of life. The affect dimension continues to increase with age until the age of 64 years old before declining to reach 69.18\% afterward (Badan Pusat Statistik, 2017).

The developmental task of late adulthood changes along with the need to adjust to new roles both personally and socially. Some of these changes potentially result in the feeling life-stress due to the stigma that old age is associated with weakness, vulnerability, and susceptibility to disease. Psychological hazards in the elderly are considered to have a more significant impact compared to previous developmental stages. As a result, late adults often experience difficulties in making social adjustment.

A preliminary study was conducted with Mbah AB (64-year-old), a person who had to be the breadwinner of her family after her husband died. Mbah $A B$, who worked as a kindergarten teacher, was saddened by the obstacles that she had to face after her husband passed away. She had to treat her first child who was diagnosed with cancer and deal with her second child who refuses to attend school. Additionally, she also had to support her grandchild financially. After retiring as a kindergarten teacher, Mbah $A B$ continued to work by doing laundry to financially support her grand daughter. As an unemployed widow, Mbah $A B$ felt responsible for raising her granddaughter because her daughter was divorced. Mbah $A B$ also stated that she felt minimum support from her family. Economic factor is the main factor of her life dissatisfaction (interview on March 18, 2018). Our interview shows that economic changes in elderly people may cause life-dissatisfaction, particularly when there is minimal perceived family support that makes such burden is heavier to bear. This affects the happiness of the elderly. In line with Diener \& Scollon (2003), all the happiest people have good social relationships, whether in the form of family, friends and romantic relationships. Warr (2011) states that in general, happy older adults are more aware and more prepared to be tied to new activities compared to older people who feel unhappy.

Subjective well-being is important because it is considered the ultimate goal of life. People who are happy see the world as being much safer shows more cooperative behavior,more energetic and satisfied with their lives (Jivraz, et al., 2014). The impact of happiness on the life of individuals is that individuals are more energetic, optimistic, confident and happier (Ariani, 2012).

Based on the above phenomena, it is essential to look at the picture and factors that influence subjective well-being of woman in late adulthood. The results of the study 
can be used as a reference for counselors to make subjective well-being in elderly women one of the things that need to be considered in providing guidance and counseling services.

\section{METHODOLOGY}

This research method uses a qualitative research method with a phenomenological approach which aims to identify phenomena regarding life experiences in woman workers. Participants were a total of six interviews with six different people were carried out in Yogyakarta and Madura. The sampling technique in this study was purposive sampling. Criteria for research subjects are elderly women aged 60 years and over and are elderly retirees. This study uses data collection methods through deep interview. The interview technique used in this study is a semi-structured interview. The purpose of this interview is to explore problems openly and deeply. And then the analysis technique in this study is content analysis.

\section{FINDING AND DISCUSSION}

Interviews revealed that the participants describe their life satisfaction in several aspects: work, health, and productive activities. We found that having a job that they desire before retirement has a positive influence on the participants' life satisfaction. Also, the work environment and coworkers also affected the satisfaction of the elderly, as mentioned during the interview:

"I am satisfied when working because of the work environment and colleagues, besides, being a teacher for me is not only for this life, but I'm also considering that it would be good for the afterlife because we're teaching knowledge to others." (Subject 3, EF)

"My job was in the finance department at an information department. Alhamdulillah, I feel like home, the people are nice. " (Subject 4, GH)

The results of the interviews presented above are supported by the Sucipto \& Rinawati (2017) who found that the elderly will feel life satisfaction when they continue to be involved in social activities, interact and carry out activities that are beneficial to others. Meanwhile, Other interviews highlight that health is one form of satisfaction for people in their late adulthood. Participants show various behavior to express their gratitude towards the health and longevity that they felt. These activities include maintaining a diet, regularly studying, and joining the elderly gymnastics. The following are the quote for the interview.

"Alhamdulillah, well, just be healthy. I'm grateful that I could still work and do various activities at my age. It's because I often drink herbal medicine. If you are not healthy, you will not be able to work, and thus, you cannot have income. " (Subject 1, AB)

"Yes, I have been blessed with health, so I maintain my diet, I am happy to join the exercise in the elderly gym at my hometown, twice a week. Yes it's gymnastics, so it's not energetic, but here is aerobic but the gym was not joined by the elderly." (Subject 2, CD)

Subjects obtained satisfaction by doing their daily activities. The various activities carried out were establishing a friendship, recitation, Empowerment of Family Welfare (PKK) activities and looking after grandchildren. This productive activity is considered beneficial after getting a pension. They make the participants feel satisfied with their daily activities.

"If now the difference is not teaching anymore, so just doing stuff at home, because a long time ago I still lived in the city where there were still PKK activities in the afternoon." (Subject 2, CD)

"Benefits taken after retirement is that I have more time... I am enjoying it. Compared with the past, the reading Quran was limited, after that, the cooking is just for a minute. But now, I can read two or one juz, I can fix the house, read the book, fix the flowers. 


\section{2 | PSIKOPEDAGOGIA}

JURNAL BIMBINGAN DAN KONSELING

Vol.8, No.1, June 2019

Thank God, you gave me plenty of time. " (Subject 6, KL)

Based on the interview, participants also reported feeling calm after doing a lot of worship such as dhikr, prayer and recitation.

"If it is not balanced with prayer, recitation, prayer, it is not good, right?, because it is the worship that makes you calm, calm." (Subject 2, CD)

"In the past, the reading Quran was limited, Moreover, I can only cook for a minute. If now, thank God I am happy because in a day I can read 2 or 1 juz " (Subject 6, KL)

Additionally, good social relations with colleagues, siblings, children and grandchildren also creates a positive picture of happiness.

"Besides that, meeting friends makes me happy, I can share with people of my age" (Subject 2, CD)

"Yes, I often meet with my friends, sometimes I go there because it's far away for them to come here, I often go there when I was still very active, but after separating with my husband, I crashed from motorcycle for a couple of time, and then, I stopped riding with motorcycle. I met them so that I would not be bored." (Subject 2, CD)

In line with the statements conveyed by the informants, previous research has also proven that one form of life satisfaction can be expressed through gratitude and the building of positive relationships with the surrounding environment (A'yun, et al., 2018). According to informants, they feel happy when they have more time. In other words, free time can be used for activities with their grandchildren. This include taking care and meeting them, as well as watching them grow up and go to school.

"The feeling of meeting my grandchildren, it's entertaining, if they aren't here it would be too quiet. I am glad because I have more time to meet my grandchildren." (Subject 2, CD)
"The feeling that arise when meeting my grandchildren helps to refresh my mind, makes me happy, especially when I'm retired, more time at home" (Subject 5, IJ)

There were also several informants who reported feeling happy when they were able to achieve their dreams and saw their children obeying them.

"On of the factors for my happiness is knowing that my children already have their own house, all 4 grandchildren are girls, jobs are also easy to get because they became civil servants while they're graduated. My children who took master degrees have also graduated and I has seen the results of my hard work when selling something with the help of my children." (Subject 3, EF)

"Another thing that makes me happy is seeing the kids succeed, all three of them are married. It's too bad that none of them became a civil servant, but at least they have a successful career as an entrepreneur (Subject 5, IJ)

The form of family support given by the family to informants such as delivering informants to take part in elderly gymnastics, allowing informants to be active in the organization and anything as long as it is positive and beneficial.

"Alhamdulillah, I have family support, if there is no one who can pick me up to the gymnastics, then I will go by myself using online transportation (Gojek) that were taught by my grandchildren. Because the gym is usually in the morning, while my children is supposed to drop off their children to the schools, so I use Gojek in the morning to go to the gym" (Subject 2, CD)

"The family still supports me, but they've asked me to reduce my activities like PKK, preferring that I join 
the recitation activity only." (Subject $\mathbf{5}$, IJ)

The type of work that participants does before their retirement influences their level of satisfaction during retirement. In addition to the preferred work, the work environment and coworkers also affect the satisfaction of people in their late adulthood. According to Indriana (2012), the more positive a person's attitude towards work, the more negative his or her attitude will be towards retirement, especially if the job is essential to his or her life.

Also, health determines informants' life satisfaction. Researchers found that health is vital to be maintained. Therefore, there are various kinds of ways that people in their late adulthood do to maintain health, such as drinking traditional herbal medicine, taking part in elderly exercises and maintaining a healthy diet. The results of the study found that health allows people in their late adulthood to carry out their daily activities. A study by Douma, et al. (2017) supports this finding, stating that the life satisfaction of late adults is seen through multidimensional aspects: social life, activities, and health.

The findings of subsequent life satisfaction are productive activities. Seniors get satisfaction by doing their daily activities. This is in line with the results of research conducted by Fitriyadewi \& Suarya (2016), that the higher the social interaction carried out by the elderly, the higher the life satisfaction of the elderly, and vice versa, if the social interaction carried out by the elderly is low, the elderly's life satisfaction is also low. The various activities that are carried out are establishing a friendship, recitation, PKK activities and looking after grandchildren. Activity theory argues that only by continuing to carry out various activities can late adults achieve life satisfaction. Continuing to be active ignite satisfaction. Activities carried out are not intended to improve physical and cognitive abilities, but rather are directed so that older adults can still carry out daily living activities. Indriana (2012) revealed that the maintenance of this function was intended so that they could remain independent, besides being able to maintain their cognitive abilities.

Five factors are known to influence subjective well-being in senior women first, religiosity. Religion or religion according to Diener, et al. (2009) includes all forms of personal relations with his God. This is following the results of the study which found that the informants felt calm after much worship such as dhikr, evening prayer, and fasting. In line with the results of research by Muzakkiyah and Suharnan (2016) that there is a relationship between religiosity, selfadjustment and subjective well-being in the context of Al Hidayah Surabaya.

Second, social relations. As the results of the study found that informants consider friends as one of the factors that contribute to happiness. This is mainly because peers in the same age group are capable of exchanging ideas. The results of this study are reinforced by the study of Bahkruddinsyah (2016) which shows that some elderly who live in nursing homes find meaning in happiness in living their lives, not distressed, more comfortable and not feeling lonely. From these findings, it can be seen that the picture of happiness in people living at nursing homes can be found through intertwined social relations.

Third, free time. It was found that informants were happy when they had more free time to spend with their grandchildren. According to the informants, they particularly enjoy doing activities to care for their grandchildren as well as watching them grow up and go to school. In line with the research of Diponegoro \& Mulyono (2015), there are 14 factors that influence the level of happiness in late adults (i.e., income; age; religion; culture; thank God; physical activity; social relations; forgiveness; quality of life; friendship; health; marriage; good relations with children, grandchildren, and daughter-inlaw; and having good relations with siblings).

Fourth, success. The results of the research obtained from the informants who said that the happiness factor that was felt was when they saw their children obeying their parents. Indriana (2012) argues that if children respect parents in any situation, it 


\section{4 | PSIKOPEDAGOGIA}

JURNAL BIMBINGAN DAN KONSELING

Vol.8, No.1, June 2019

creates a positive self-image that enables late adults to achieve happiness in their lives.

Fifth, family support. The form of family support given by the family to informants such as delivering informants to take part in elderly gymnastics, allowing informants to be active in the organization or any other positive and beneficial activities. The same result was discovered by the Pali study (2016) who noted that people in their late adulthood are happy with living in a nursing home because their needs are met. However, other studies stated that the elderly felt happy when living with their families. From these findings, it is clear that families influence the level of happiness of seniors. Taylor (2009) explained that family social support is needed because the problems faced by late adults are related to psychological well-being such as decreasing financial resources, and the strength of functions.

The five factors that affect the subjective well-being of senior women are basically very important, therefore an effort is needed to develop them. One effort that can be done is through elderly counseling. This is supported by the results of research conducted by Triningtyas \& Muhayati (2018) that elderly counseling can help the elderly in building self-acceptance and readiness to enter retirement. So that through elderly counseling can develop subjective welfare for senior women.

\section{CONCLUSION}

Our findings provide a description and information on the factors that influence the subjective well-being of retired senior women. In conclusion, subjective well-being in senior women is influenced by the existence of life satisfaction in the form of job satisfaction, health, and productive activities. Meanwhile, several factors that influenced subjective well-being in senior women include religious, social relations, leisure time, success and family support. . Efforts can be made to develop subjective wellbeing in senior women through elderly counseling. The results of this study can be used as a reference for future researchers in increasing life satisfaction in the elderly.

\section{REFERENCES}

Ariani, M. A. (2012). Storytelling untuk meningkatkan happiness pada lansia yang tinggal di panti werdha. Tesis. Malang: Universitas Muhammadiyah Malang.

A'yun, M. Q., Tentama, F., \& Situmorang, N. Z. (2018). A description of female pesantren students' subjective wellbeing. Psikopedagogia, 7(1), 1-8.

Badan Pusat Statistik. (2017). Indeks kebahagiaan tahun 2017. Diakses https://www.bps.go.id/.

Bahkruddinsyah, R. (2016). Makna hidup dan arti kebahagiaan pada lansia di panti werdha nirwana puri Samarinda. eJournal Psikologi, 4(4), 431-445.

Diener, E. (1984). Subjective well being. Psychological Buletin. 95 (3), 542-575.

Diener, E., Scollon, C. N., \& Lucas, R. E. (2009). The evolving concept of subjective well-being: the multifaceted nature of happiness.

Diener, E., \& Scollon, C., (2003). Subjective well-being is desirable, but not the summum bonum. (Handout for University of Minnesota.

Diponegoro, M. A, \& Mulyono. (2015). Faktor-faktor psikologis yang mempengaruhi kebahagiaan pada lanjut usia suku jawa di klaten. Jurnal Psikopedagogia, 5(1), 13-19.

Douma, L., Steverink, N., Hutter, I., \& Meijering, L. (2017). Exploring subjective well-being in older age by using participant-generated word clouds. Journal The Gerontologist, 57(2), $229-239$.

Fitriyadewi, L. P. W., \& Suarya, L. M. K. S. (2016). Peran interaksi sosial terhadap kepuasan hidup lanjut usia. Jurnal Psikologi Udayana, 3(2), 332-341.

Forgeard, M. J., Jayawickreme, E., Kern, M. L., \& Seligman, M. E. (2011). Doing the right thing: measuring wellbeing for public policy. International journal of wellbeing, 1(1). 
Hofmann, W., Luhmann, M., Fisher, R. R., Vohs, K. D., \& Baumeister, R. F. (2014). Yes, but are they happy? Effects of trait self-control on affective well-being and life satisfaction. Journal of personality, 82(4), 265-277.

Hurlock, E. B. (2002). Psikologi perkembangan suatu pendekatan sepanjang rentang kehidupan. Jakarta: Erlangga.

Indriana. (2012). Gerontologi \& progeria. Yogyakarta: Pustaka Pelajar.

Jivraz, S., Nazroo, J., Vanhoutte, B., \& Chandola, T. (2014). Aging and subjective well-being in later life. The Journals of Gerontology, 69(6), 930941.

Muzakkiyah, N., \& Suharnan. (2016). Religiusitas, penyesuian diri dan subjective well-being. Jurnal Psikologi Indonesia, 5(1), 28-38.

Ngamaba, K. H. (2016). Happiness and life satisfaction in rwanda. Journal of Psychology in Africa, 26(5), 407-414.

Pali. C. (2016). Gambaran kebahagiaan pada lansia yang memilih tinggal di panti werdha. Jurnal e-biomadik, 4(1), 1-7.

Papalia, Olds, \& Feldman. (2009). Human development. Jakarta: Kencana.

Rask, K., Astedt, K., Paivi, A. L., \& Pekka. (2009). Adolescent subjective wellbeing and realize values. Journal of Advanced Nursing, 38(3), 254-263.

Santrock. (2012). Life-span development, perkembangan masa hidup. Jakarta: Erlangga.

Shipp, A. J., Edwards, J. R., \& Lambert, L. S. (2009). Conceptualization and measurement of temporal focus: the subjective experience of the past, present, and future. Organizational Behavior and Human Decision Processes, 110(1), 1-22.

Sucipto, S., \& Rinawati, F. (2017). Pengaruh kesehatan dan pekerjaan terhadap kepuasan hidup pada lansia di posyandu lansia kelurahan balowerti kota Kediri. Jurnal IImu Kesehatan, 5(2), 103-105.
Suikkanen, J. (2011). An improved whole life satisfaction theory of happiness. International Journal of Wellbeing, 1(1).

Taylor, S. E. (2009). Health psychology. New York: McGraw Hill Inc

Triningtyas, D. A., \& Muhayati, S. (2018). Konseling lansia: upaya lanjut usia dalam membangun kemandirian hidup dan penerimaan diri terhadap kesiapan memasuki masa pensiun (studi pada lansia di bina keluarga lansia posyandu cempaka kabupaten ngawi). JKI (Jurnal Konseling Indonesia), 4(1), 16-21.

Warr, P. (2011). Work, happiness, and unhappiness. Psychology Press. 